УДК 39(397.4)

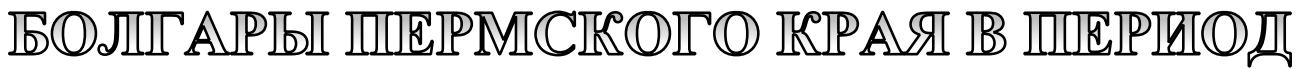

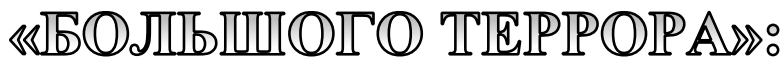

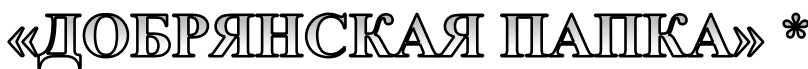

\author{
Д.И. Вайман, Пермский федеральный исследовательский центр УрО РАН
}

\author{
Для цитирования: \\ Вайман Д.И. Болгары Пермского края в период «Большого террора»: «Добрянская папка» // Вестник Пермского \\ федерального исследовательского центра. - 2021. - № 4. - С. 82-41. https://doi.org/10.7242/2658-705X/2021.4.8
}

На основе архивных материалов рассматривается история репрессий среди болгар Добрянского района в период «большого террора». «Добрянская папка» - условное название архивно-следственных дел - по болгарам Добрянского района Пермского края. В содержании дел: обвинительные приговоры, анкетные данные, письма, автобиографии, протоколы допросов, справки, ответы на запросы и прочие документы. Все эти источники позволяют создать социокультурный портрет болгар в Добрянском районе, а также представить некоторые обстоятельства репрессивной политики в отношении болгарского сообщества, проводившейся не только по социальному, но и по национальному признакам в этот период. По Добрянскому району в период Большого террора пострадало самое большое число болгар в регионе. Подвергшиеся репрессиям болгары проходили по уголовным делам по ст. 58-2-9-8-11 УК РСФСР как члены диверсионно-повстанческой организации.

Ключевые слова: болгары в России, история болгар в 1930-е годы, архивные дела, следственные дела, болгары в Пермском крае.

Обращение к теме болгарского сообщества, истории его формирования в регионе трудно представить без всестороннего историко-культурного контекста. В этой связи обращение к фондам Пермского государственного архива социально-политической истории позволяют взглянуть на некоторые обстоятельства становления болгарского сообщества в регионе, которое формировалось в регионе в результате нескольких миграционных волн XX в. - добровольных и принудительных миграций
[13, с. 187-190]. Архивно-следственные дела, представленные в фондах Пермского государственного архива социально-политической истории (ПермГАСПИ) выступают важным источником по истории болгарского сообщества Пермского Прикамья первой половины XX в. [14, С. 89-96].

Рассмотрение дел периода «Большого террора» позволяет сформировать социальный портрет проходивших по этим делам болгар, а также их семей. В делах присутствует описание состава семьи арестован-

\footnotetext{
* Статья подготовлена в рамках проекта РФФИ №19-59-18003 «Болгары Урала и Сибири
} в XX-XXI веках: история, культура, идентичность». 
ных, степень их образования, профессиональная занятость на момент ареста и другие данные. Обращение к материалам дел позволяет реконструировать причины и обстоятельства миграционных передвижений болгарского населения, участие болгар в экономической жизни региона, обстоятельства репрессивной политики в отношении болгар. В частности, основной задачей настоящей статьи является рассмотрение национального аспекта репрессивной политики конца 1930-х гг. среди болгар Пермской области [3, с. 66-73; 8, с. 144-207].

Период политических репрессий 1937-1938 гг. известен в отечественной историографии под названием «большой террор». Начало массовых репрессий принято связывать с приказом НКВД № 00447 от 30 июля 1937 года (Оперативный приказ народного комиссара внутренних дел СССР № 00447 «Об операции по репрессированию бывших кулаков, уголовников и других антисоветских элементов») [2]. Данный документ давал полную свободу действий в реализации репрессивной политики: «Перед органами государственной безопасности стоит задача самым беспощадным образом разгромить всю эту банду антисоветских элементов, защитить трудящийся советский народ от их контрреволюционных происков, наконец, раз и навсегда покончить с их подлой подрывной работой против основ советского государства...» [2].

По мнению исследователей, пик большого террора пришелся на осень 1937 г. Операция по уничижению потенциально опасных элементов имела централизованный характер. Репрессии задели разные слои общества, коснулись, в том числе, и представителей разных национальностей $[15$, с. $87-89 ; 12$, с. $25-26]$.

В Прикамье аресты совершались местными районными отделениями НКВД. Вышестоящее Свердловское НКВД присылало оперативные бригады для организации и обучения пермских сотрудников. На местах быстро осваивались методы фабрикации дел и ускоренного ведения следствия $[15$, c. 11$]$.

\section{Болгары Добрянского района}

История появления болгар в Прикамье, наряду с другими этнодисперсными группами $[9$, с. 17-37; 1, с. 21-33] охватывает сравнительно небольшой хронологический временной отрезок, пик которого приходится на конец XIX - половину XX века. Согласно материалам переписи 1926 г., на территории Уральской области проживало 49 болгар (40 мужчин и 9 женщин). Болгары проживали в Троицком, Шадринском, а также в центральном (Свердловском) округах Свердловской области. Наиболее значительный миграционный приток болгар на Урал приходится на 1930-е гг. и связан он с кампанией по раскулачиванию и принудительному выселению. В результате, численность болгар на Урале увеличивается более чем в 20 раз. По данным Всесоюзной переписи населения 1939 г., на территории Пермской, Свердловской и Челябинской областей проживало 1188 болгар, большая часть из которых - в Челябинской области - 854 чел., в Свердловской области - 188 чел., в Пермской области 146 чел. [13, с. 189-190].

С начала 1930-х годов несколько территорий Пермской области, в том числе Добрянский район, становятся местом спецпоселения трудпоселенцев - раскулаченных Украинской ССР и Молдавской АССР, из районов традиционного расселения болгар со второй половины XIX в. Аресты болгар в Пермской области проводились повсеместно, однако их наибольшее число приходится на Добрянский район. Причиной служит тот факт, что в конце 1930-х годов болгары не проживали только в шести из 42 районов Пермской области, а больше всего их было в Добрянском районе - 33 человека [10, с. 25].

Большинство репрессированных болгар являлись уроженцами с. Терновка Николаевского района Одесской области и с. Парканы Тираспольского района Молдавской ACСР. В Добрянском районе они проживали в поселках Верхний Исток и Ключанка. Всего по Добрянскому району в период Большого террора проходят 14 человек болгар по национальности (табл. 1). Соци 
Таблица 1

\begin{tabular}{|c|c|c|c|c|c|}
\hline ФИO & $\begin{array}{c}\text { Год } \\
\text { рождения }\end{array}$ & $\begin{array}{l}\text { Возраст } \\
\text { на } \\
\text { момент } \\
\text { ареста } \\
\end{array}$ & $\begin{array}{c}\text { Место } \\
\text { рождения }\end{array}$ & $\begin{array}{c}\text { Место } \\
\text { жительства }\end{array}$ & Специальность \\
\hline $\begin{array}{l}\text { Баев Иван } \\
\text { Гордеевич }\end{array}$ & 1881 & 57 & $\begin{array}{l}\text { Ольшанский р-н, } \\
\text { Одесская обл., } \\
\text { уССР }\end{array}$ & $\begin{array}{l}\text { п. Ключанский, } \\
\text { Добрянский р-н, } \\
\text { Пермская обл. }\end{array}$ & $\begin{array}{l}\text { плотник по } \\
\text { спецзаказам }\end{array}$ \\
\hline $\begin{array}{l}\text { Грудолов Филипп } \\
\text { Григорьевич }\end{array}$ & 1878 & 59 & $\begin{array}{l}\text { с. Парканы, } \\
\text { Тираспольский р-н, } \\
\text { Молдавская АССР }\end{array}$ & $\begin{array}{l}\text { п. Верхний Исток, } \\
\text { Добрянский р-н, } \\
\text { Пермская обл. }\end{array}$ & плотник c/x артели \\
\hline $\begin{array}{l}\text { Кабакчей } \\
\text { Леонтий } \\
\text { Александрович }\end{array}$ & 1900 & 37 & $\begin{array}{l}\text { д. Лозовотка, } \\
\text { Ольшанский р-н, } \\
\text { Одесская обл., } \\
\text { уССР }\end{array}$ & $\begin{array}{l}\text { п. Ключанка, } \\
\text { Добрянский р-н, } \\
\text { Пермская обл. }\end{array}$ & $\begin{array}{l}\text { строитель Ключанской } \\
\text { c/x артели }\end{array}$ \\
\hline $\begin{array}{l}\text { Киров Василий } \\
\text { Иванович }\end{array}$ & 1906 & 31 & $\begin{array}{l}\text { с. Парканы, } \\
\text { Тираспольский р-н, } \\
\text { Молдавская АССР }\end{array}$ & $\begin{array}{l}\text { п. Верхний Исток, } \\
\text { Добрянский р-н, } \\
\text { Пермская обл. }\end{array}$ & $\begin{array}{l}\text { уполномоченный c/x } \\
\text { артели }\end{array}$ \\
\hline $\begin{array}{l}\text { Киров Иван } \\
\text { Филиппович }\end{array}$ & 1878 & 59 & $\begin{array}{l}\text { с. Парканы, } \\
\text { Тираспольский р-н, } \\
\text { Молдавская АССР }\end{array}$ & $\begin{array}{l}\text { п. Верхний Исток, } \\
\text { Добрянский р-н, } \\
\text { Пермская обл. }\end{array}$ & скотовод п. В. Исток \\
\hline $\begin{array}{l}\text { Корниз Степан } \\
\text { Степанович }\end{array}$ & 1901 & 36 & $\begin{array}{l}\text { с. Парканы, } \\
\text { Тираспольский р-н, } \\
\text { Молдавская АССР }\end{array}$ & $\begin{array}{l}\text { п. Ключанский, } \\
\text { Добрянский р-н, } \\
\text { Пермская обл. }\end{array}$ & $\begin{array}{l}\text { лесоруб Ключанской } \\
\text { тракторной базы }\end{array}$ \\
\hline $\begin{array}{l}\text { Пильтек } \\
\text { Григорий } \\
\text { Федорович }\end{array}$ & 1917 & 20 & $\begin{array}{l}\text { с. Парканы, } \\
\text { Тираспольский р-н, } \\
\text { Молдавская АССР }\end{array}$ & $\begin{array}{l}\text { п. Верхний Исток, } \\
\text { Добрянский р-н, } \\
\text { Пермская обл }\end{array}$ & Рабочий-лесоруб \\
\hline $\begin{array}{l}\text { Пильтек } \\
\text { Иван Федорович }\end{array}$ & 1914 & 23 & $\begin{array}{l}\text { с. Парканы, } \\
\text { Тираспольский р-н, } \\
\text { Молдавская АССР }\end{array}$ & $\begin{array}{l}\text { п. Верхний Исток, } \\
\text { Добрянский р-н, } \\
\text { Пермская обл }\end{array}$ & $\begin{array}{l}\text { Плотник-строитель } \\
\text { Ключанской } \\
\text { тракторной базы }\end{array}$ \\
\hline $\begin{array}{l}\text { Радулов Петр } \\
\text { Иванович }\end{array}$ & 1909 & 28 & $\begin{array}{l}\text { с. Парканы, } \\
\text { Тираспольский р-н, } \\
\text { Молдавская АССР }\end{array}$ & $\begin{array}{l}\text { п. Верхний Исток, } \\
\text { Добрянский р-н, } \\
\text { Пермская обл. }\end{array}$ & бригадир c/х артели \\
\hline $\begin{array}{l}\text { Радулов Иван } \\
\text { Иванович }\end{array}$ & 1919 & 18 & $\begin{array}{l}\text { с. Парканы, } \\
\text { Тираспольский р-н, } \\
\text { Молдавская АССР }\end{array}$ & $\begin{array}{l}\text { п. Верхний Исток, } \\
\text { Добрянский р-н, } \\
\text { Пермская обл. }\end{array}$ & c/x артель \\
\hline $\begin{array}{l}\text { Радулов } \\
\text { Григорий } \\
\text { Иванович }\end{array}$ & 1911 & 26 & $\begin{array}{l}\text { с. Парканы, } \\
\text { Тираспольский р-н, } \\
\text { Молдавская АССР }\end{array}$ & $\begin{array}{l}\text { п. Верхний Исток, } \\
\text { Добрянский р-н, } \\
\text { Пермская обл. }\end{array}$ & $\begin{array}{l}\text { лесоруб Ключанской } \\
\text { тракторной базы }\end{array}$ \\
\hline $\begin{array}{l}\text { Раичев Захар } \\
\text { Федорович }\end{array}$ & 1892 & 45 & $\begin{array}{l}\text { д. Парканы, } \\
\text { Тираспольский р-н, } \\
\text { Молдавская АССР }\end{array}$ & $\begin{array}{l}\text { п. Верхний Исток, } \\
\text { Добрянский р-н, } \\
\text { Пермская обл. }\end{array}$ & Плотник-строитель \\
\hline $\begin{array}{l}\text { Станов Владимир } \\
\text { Андреевич }\end{array}$ & 1911 & 26 & $\begin{array}{l}\text { с. Парканы, } \\
\text { Тираспольский р-н, } \\
\text { Молдавская АССР }\end{array}$ & $\begin{array}{l}\text { п. Верхний Исток, } \\
\text { Добрянский р-н, } \\
\text { Пермская обл. }\end{array}$ & лесоруб \\
\hline $\begin{array}{l}\text { Стоянов Василий } \\
\text { Никифорович }\end{array}$ & 1896 & 41 & $\begin{array}{l}\text { с. Парканы, } \\
\text { Тираспольский р-н, } \\
\text { Молдавская АССР }\end{array}$ & $\begin{array}{l}\text { п. Исток, } \\
\text { Добрянский р-н, } \\
\text { Пермская обл. }\end{array}$ & $\begin{array}{l}\text { заведующий } \\
\text { магазином } \\
\text { Райлеспромторга в } \\
\text { пос. Добрянка }\end{array}$ \\
\hline
\end{tabular}

альное происхождение всех арестованных - крестьяне, после раскулачивания сосланные на трудовое поселение в Добрянский район. Партийное положение арестантов - беспартийные, все граждане СССР, уровень образования - начальный. Все имели трудоустройство в по- селках по месту проживания, трудились в сельхозартели, на тракторной базе, заготавливали лес и т.д. (см. табл. 1).

Согласно материалам допросов архивно-следственных дел, с конца 1937-начала 1938 г. сотрудники Пермского ГО НКВД в составе следственной бригады 
выезжали в Добрянский район для проведения там массовых арестов среди находившихся на спецпоселении трудпоселенцев - бывших кулаков. В конце декабря 1937 г. только за 5 суток следственных мероприятий было арестовано более 120 человек, в том числе и болгар. Аресты людей производились путем вызова их в поселковую комендатуру, далее они направлялись в Пермскую тюрьму [4, Оп.1 Д.16778. Л.26].

Арестам были подвержены в первую очередь категории граждан, потенциально не лояльных политическому режиму, в частности - это люди, проходившие по спискам трудпоселенцев, а также лица, имеющие национальность капиталистических государств, которые априори были враждебны для советской социалистической системы. В данном ключе можно с уверенностью утверждать о социальном и национальном аспекте репрессий. Задержанные болгары обвинялись в связях с разведкой иностранных государств и в результате были выведены как участники шпионско-диверсионной организации, созданной иностранной разведкой.

Типичным примером дела периода «Большого террора» является дело на арестованного Кирова Василия Ивановича, 1906 г.p., болгарина, гражданина СССР, «бывшего кулака», уроженца деревни Парканы Тираспольского района МАССР раскулаченного в 1931 г. и высланного на Урал, находящегося на трудпоселении в поселке Верхний Исток Добрянского района, где он являлся уполномоченным сельскохозяйственной артели. На поселении Киров В.И. находился с семьей в составе: жена - Варвара Дмитриевна, 28 лет; дочь - Аксения, 9 лет; сын - Павел, 7 лет; дочь - Мария, 4 года; дочь - Нина, 1 месяц. [4, Оп.1 Д.13827 Л.4] Арест Кирова В.И. был произведен 10.12.1937 г. Пермским гор. Отделом НКВД. В обвинительном заключении значится, что Киров В.И. являлся участником эстонской повстанческой организации и вел повстанческую работу. В частности, «вел подготовку вооруженного восстания к периоду возникновения войны капиталистических государств в СССР» [4, Оп.1 Д.13827. Л.8]. В чем именно заключалась «подготовка вооруженного восстания» из материалов дел не видно.

На основании протоколов допроса дело по обвинению Кирова В.И. было направлено в ГУГБ НКВД СССР для внесудебного рассмотрения. Приговор - высшая мера наказания (ВМН) - расстрел. В обвинительном заключении Кирова Василия Ивановича значится, что виновным он себя признал. Приговор в отношении Кирова В.И. приведен в исполнение 15.02.1938 г. [4, Оп.1 Д.13827. Л.8].

Киров В.И. упоминается в протоколах допроса других болгар, задержанных по обвинению в шпионаже, также проходивших по статье 58. Так, например, отмечено, что Киров В.И. в 1935 г. завербовал Стоянова В.Н. в эстонскую диверсионноповстанческую организацию. Стоянов по заданию Кирова в 1936 г. осуществил поджог лесного массива Добрянского леспромхоза, уничтожив большую площадь лесов. Далее Киров В.И. упоминается в деле Грудолова Ф.Г., которого он привлек в повстанческую организацию. Грудолов Ф.Г., в свою очередь, по приказу организации якобы совершил поджог лесных массивов*. Кроме того, должен был распускать в день выборов слухи о начале войны между СССР и фашистской Германией [4, Оп.1 Д.16778. Л.14]. Показания названых лиц в ходе следствия не проверялись. Каких-либо доказательств их преступной деятельности на момент ареста в распоряжении органов НКВД не имелось.

Репрессированные болгары Добрянского района значатся как члены подпольных организаций, о практической

\footnotetext{
* Из показаний свидетеля по дополнительной проверке уголовного дела в 1988 г. выяснилось, что ни поджогов, ни пожаров, возникших на территории Добрянского леспромхоза, в этот период времени зафиксировано не было [4, Оп.1 Д.16878. Л.14].
} 
деятельности которых из материалов дел ничего не известно. Обвинение строилось на причастности болгар к антисоветским диверсионным организациям и шпионаже в пользу иностранных разведок (табл. 2).

Арестованные проходили по ст. 58-29-8-11 УК РСФСР, обвинялись в шпионской деятельности в пользу иностранных разведок Эстонии, Германии, Болгарии. В трудовых поселках Добрянского района помимо болгар проживали эстонцы, a также представители других народов, подвергшихся репрессиям. По статье «шпионаж» в Добрянском районе проходило много эстонцев. В этой связи большинство сфабрикованных шпионских дел по болгарам Добрянского района проходили по обвинению в шпионаже в пользу Эстонии.

Таблица 2

\begin{tabular}{|c|c|c|c|c|c|c|}
\hline ФИО & Обвинение & Деятельность & Арест & Приговор & $\begin{array}{c}\text { Исполнение } \\
\text { приговора }\end{array}$ & $\begin{array}{c}\text { Реабили- } \\
\text { тирован }\end{array}$ \\
\hline $\begin{array}{l}\text { Баев Иван } \\
\text { Гордеевич }\end{array}$ & $\begin{array}{l}\text { Шпионская } \\
\text { деятельность в } \\
\text { пользу Эстонии }\end{array}$ & $\begin{array}{l}\text { C } 1935 \text { г. являлся агентом } \\
\text { эстонской разведки и входил } \\
\text { в состав диверсионно- } \\
\text { повстанческой организации. В } \\
1937 \text { г. совершил поджог } \\
\text { склада оружейных заготовок. } \\
\text { Принимал участие в } \\
\text { подготовке к вооруженному } \\
\text { восстанию против Советской } \\
\text { власти }\end{array}$ & $\begin{array}{l}\text { Декабрь } \\
1937 \text { г. }\end{array}$ & $\begin{array}{l}\text { ВМH/ } \\
\text { Январь } \\
1937 \text { г. }\end{array}$ & Май 1938 г. & $\begin{array}{l}\text { Август } \\
1971 \text { г. }\end{array}$ \\
\hline $\begin{array}{l}\text { Грудалов } \\
\text { Филипп } \\
\text { Григорьевич }\end{array}$ & $\begin{array}{l}\text { Участие в } \\
\text { антисоветской } \\
\text { диверсионной } \\
\text { организации. }\end{array}$ & $\begin{array}{l}\text { Поджигал склад с дровами } \\
\text { леспромхоза. Совершил } \\
\text { поджог лесных массивов. } \\
\text { Должен был распускать в } \\
\text { день выборов слухи о начале } \\
\text { войны между СССР и } \\
\text { фашистской Германией }\end{array}$ & $\begin{array}{l}\text { Декабрь } \\
1937 \text { г. }\end{array}$ & $\begin{array}{l}\text { ВМH / } \\
\text { Январь } \\
1938 \text { г. }\end{array}$ & $\begin{array}{c}\text { Февраль } \\
1938 \text { г. }\end{array}$ & $\begin{array}{l}\text { Ноябрь } \\
1975 \text { г. }\end{array}$ \\
\hline $\begin{array}{l}\text { Кабакчей } \\
\text { Леонтий } \\
\text { Александрович } \\
\end{array}$ & Шпионаж & $\begin{array}{ll}\text { Являлся } & \text { участником } \\
\text { диверсионной организации }\end{array}$ & $\begin{array}{l}\text { Декабрь } \\
1937 \text { г. }\end{array}$ & $\begin{array}{c}\text { ВMH / } \\
\text { Январь } \\
1937 \text { г. }\end{array}$ & $\begin{array}{c}\text { Февраль } \\
1938 \text { г. }\end{array}$ & $\begin{array}{c}\text { Март } \\
1989 \text { г. }\end{array}$ \\
\hline $\begin{array}{l}\text { Киров Василий } \\
\text { Иванович }\end{array}$ & $\begin{array}{l}\text { Повстанческая } \\
\text { деятельность в } \\
\text { пользу Эстонии }\end{array}$ & $\begin{array}{l}\text { Вел подготовку вооруженного } \\
\text { восстания к периоду } \\
\text { возникновения } \\
\text { капиталистических государств } \\
\text { в СССР } \\
\end{array}$ & $\begin{array}{c}\text { Декабрь } \\
1937 \text { г. }\end{array}$ & $\begin{array}{l}\text { ВМH / } \\
\text { Январь } \\
1937 \text { г. }\end{array}$ & $\begin{array}{l}\text { Март } \\
1938 \text { г. }\end{array}$ & $\begin{array}{c}\text { Май } \\
1959 \text { г. }\end{array}$ \\
\hline $\begin{array}{l}\text { Киров Иван } \\
\text { Филиппович }\end{array}$ & $\begin{array}{l}\text { Шпионская } \\
\text { деятельность в } \\
\text { пользу Эстонии } \\
\end{array}$ & $\begin{array}{lr}\text { Являлся } & \text { участником } \\
\text { эстонской } & \text { диверсионной } \\
\text { организации } & \\
\end{array}$ & $\begin{array}{l}\text { Декабрь } \\
1937 \text { г. }\end{array}$ & $\begin{array}{c}\text { ВMH / } \\
\text { Январь } \\
1937 \text { г. }\end{array}$ & $\begin{array}{c}\text { Март } \\
1938 \text { г. }\end{array}$ & $\begin{array}{c}\text { Апрель } \\
1959 \text { г. }\end{array}$ \\
\hline $\begin{array}{l}\text { Корниз Степан } \\
\text { Степанович }\end{array}$ & $\begin{array}{l}\text { Участие в } \\
\text { антисоветской } \\
\text { диверсионной } \\
\text { организации }\end{array}$ & $\begin{array}{l}\text { Поджигал дровяные склады и } \\
\text { лесные массивы, а также вел } \\
\text { антисоветскую агитацию и } \\
\text { пропаганду }\end{array}$ & $\begin{array}{c}\text { Декабрь } \\
1937 \text { г. }\end{array}$ & $\begin{array}{l}\text { ВМH / } \\
\text { Январь } \\
1938 \text { г. }\end{array}$ & $\begin{array}{l}\text { Январь } \\
1938 \text { г. }\end{array}$ & $\begin{array}{l}\text { Ноябрь } \\
1975 \text { г. }\end{array}$ \\
\hline $\begin{array}{l}\text { Пильтек } \\
\text { Григорий } \\
\text { Федорович }\end{array}$ & $\begin{array}{l}\text { Повстанческая } \\
\text { деятельность в } \\
\text { пользу Эстонии }\end{array}$ & $\begin{array}{lr}\text { Участвовал } & \text { в подготовке } \\
\text { убийства } & \text { председателя } \\
\text { участковой } & \text { избирательной } \\
\text { комиссии Балдина. Принимал } \\
\text { участие в травле лучших } \\
\text { стахановцев }\end{array}$ & $\begin{array}{c}\text { Декабрь } \\
1937 \text { г. }\end{array}$ & $\begin{array}{c}10 \text { лет } \\
\text { лишения } \\
\text { свободы }\end{array}$ & $\begin{array}{c}\text { Февраль } \\
1938 \text { г. }\end{array}$ & $\begin{array}{c}\text { Май } \\
1957 \text { г. }\end{array}$ \\
\hline $\begin{array}{l}\text { Пильтек Иван } \\
\text { Федорович }\end{array}$ & Шпионаж & $\begin{array}{l}\text { Террористическая } \\
\text { повстанческая } \\
\text { вредительская деятельность } \\
\text { в пользу Эстонии } \\
\end{array}$ & $\begin{array}{l}\text { Декабрь } \\
1937 \text { г. }\end{array}$ & $\begin{array}{l}\text { ВМH / } \\
\text { Январь } \\
1938 \text { г. }\end{array}$ & $\begin{array}{c}\text { Февраль } \\
1938 \text { г. }\end{array}$ & $\begin{array}{c}\text { Декабрь } \\
1988 \text { г. }\end{array}$ \\
\hline
\end{tabular}


Таблица 2 (продолжение)

\begin{tabular}{|c|c|c|c|c|c|c|}
\hline ФИО & Обвинение & Деятельность & Арест & Приговор & $\begin{array}{c}\text { Исполнение } \\
\text { приговора }\end{array}$ & $\begin{array}{c}\text { Реабили- } \\
\text { тирован }\end{array}$ \\
\hline $\begin{array}{l}\text { Радулов Петр } \\
\text { Иванович }\end{array}$ & $\begin{array}{l}\text { Диверсионно- } \\
\text { повстанческая } \\
\text { деятельность в } \\
\text { пользу } \\
\text { Болгарии }\end{array}$ & $\begin{array}{lr}\text { Умышленно } \\
\text { недоброкачественный } & \text { ремонт } \\
\text { тракторов, с целью их быстрого } \\
\text { износа и поломки. В } 1937 \text { г. на } \\
\text { период уборочной } & \text { кампании } \\
\text { подверг } \quad \text { порче } & \text { большое } \\
\text { количество хлеба } & \\
\end{array}$ & $\begin{array}{c}\text { Декабрь } \\
1937 \text { г. }\end{array}$ & $\begin{array}{l}\text { ВМH / } \\
\text { Январь } \\
1938 \text { г. }\end{array}$ & $\begin{array}{c}\text { Февраль } \\
1938 \text { г. }\end{array}$ & $\begin{array}{c}\text { Декабрь } \\
1975 \text { г. }\end{array}$ \\
\hline $\begin{array}{l}\text { Радулов Иван } \\
\text { Иванович }\end{array}$ & $\begin{array}{l}\text { Диверсионно- } \\
\text { повстанческая } \\
\text { деятельность в } \\
\text { пользу Эстонии }\end{array}$ & $\begin{array}{lcr}\text { Входил } & \text { в } & \text { состав } \\
\text { террористической } & \text { группы. } \\
\text { Поджигал лесные } & \text { массивы. В } \\
\text { период подготовки } & \text { выборов } \\
\text { Верховный } \quad \text { Совет } & \text { срывал } \\
\text { предвыборные плакаты } & \\
\end{array}$ & $\begin{array}{c}\text { Декабрь } \\
1937 \text { г. }\end{array}$ & $\begin{array}{l}\text { ВМH / } \\
\text { Январь } \\
1938 \text { г. }\end{array}$ & $\begin{array}{c}\text { Февраль } \\
1938 \text { г. }\end{array}$ & $\begin{array}{c}\text { Декабрь } \\
1975 \text { г. }\end{array}$ \\
\hline $\begin{array}{l}\text { Радулов } \\
\text { Григорий } \\
\text { Иванович }\end{array}$ & $\begin{array}{l}\text { Диверсионно- } \\
\text { повстанческая } \\
\text { деятельность в } \\
\text { пользу Эстонии }\end{array}$ & $\begin{array}{l}\text { По заданию организации в } \\
1935 \text { г. принимал участие в } \\
\text { поджоге деревянного склада } \\
\text { Добрянского Леспромхоза. В } \\
1936 \text { г. принимал участие в } \\
\text { массовом поджоге лесных } \\
\text { массивов. Призывал лесорубов к } \\
\text { вооруженной борьбе с советской } \\
\text { властью }\end{array}$ & $\begin{array}{c}\text { Декабрь } \\
1937 \text { г. }\end{array}$ & $\begin{array}{l}\text { ВМH / } \\
\text { Январь } \\
1938 \text { г. }\end{array}$ & $\begin{array}{c}\text { Февраль } \\
1938 \text { г. }\end{array}$ & $\begin{array}{c}\text { Декабрь } \\
1975 \text { г. }\end{array}$ \\
\hline $\begin{array}{l}\text { Раичев Захар } \\
\text { Федорович }\end{array}$ & $\begin{array}{l}\text { Диверсионно- } \\
\text { повстанческая } \\
\text { деятельность в } \\
\text { пользу Эстонии }\end{array}$ & $\begin{array}{l}\text { Осуществил поджог колхозного } \\
\text { склада с зерном в деревне } \\
\text { Конино, погубив пожаром } 20 \text { тонн } \\
\text { хлеба. В } 1936 \text { г. поджог два стога } \\
\text { колхозного сена. В } \quad \text { ноябре } \\
1937 \text { г. совместно с членом } \\
\text { организации - кулаком Гурьевым } \\
\text { покушался на убийство парторга } \\
\text { - председателя Избирательной } \\
\text { комиссии Валдина, произведя в } \\
\text { него выстрел в лесу. }\end{array}$ & $\begin{array}{c}\text { Декабрь } \\
1937 \text { г. }\end{array}$ & $\begin{array}{l}\text { ВМH / } \\
\text { Январь } \\
1938 \text { г. }\end{array}$ & $\begin{array}{c}\text { Февраль } \\
1938 \text { г. }\end{array}$ & $\begin{array}{c}\text { Июнь } \\
1989\end{array}$ \\
\hline $\begin{array}{l}\text { Станов } \\
\text { Владимир } \\
\text { Андреевич }\end{array}$ & $\begin{array}{l}\text { Повстанческая } \\
\text { организация }\end{array}$ & $\begin{array}{l}\text { Контрреволюционная } \\
\text { деятельность, } \quad \text { сплачивание } \\
\text { вокруг себя группы для ведения } \\
\text { контрреволюционной работы }\end{array}$ & $\begin{array}{c}\text { Октябрь } \\
1937 \text { г. }\end{array}$ & $\begin{array}{l}\text { ВМH / } \\
\text { Ноябрь } \\
1937 \text { г. }\end{array}$ & $\begin{array}{c}\text { Ноябрь } \\
\text { 1937г. }\end{array}$ & $\begin{array}{c}\text { Май } 1956 \\
\text { г. }\end{array}$ \\
\hline $\begin{array}{l}\text { Стоянов } \\
\text { Василий } \\
\text { Никифорович }\end{array}$ & $\begin{array}{l}\text { Шпионская } \\
\text { деятельность в } \\
\text { пользу Эстонии }\end{array}$ & $\begin{array}{l}\text { C } 1935 \text { г. является участником } \\
\text { эстонской } \\
\text { повстанческой диверсионно- } \\
\text { Совершил поданизации. } \\
\text { Добрянском районе. Призывал } \\
\text { население к вооруженной борьбе } \\
\text { с Советской властью. }\end{array}$ & $\begin{array}{c}\text { Декабрь } \\
1937 \text { г. }\end{array}$ & $\begin{array}{l}\text { ВМH / } \\
\text { Январь } \\
1938 \text { г. }\end{array}$ & $\begin{array}{c}\text { Февраль } \\
1938 \text { г. }\end{array}$ & $\begin{array}{c}\text { Июнь } \\
1960\end{array}$ \\
\hline
\end{tabular}

\section{Технология фабрикации}

\section{уголовных дел}

Процедура фабрикации дел включала в себя несколько этапов: арест, оформление дела, обвинительное заключение и приговор. В отношении арестованных применялись так называемые методы «упрощенного» следствия. Санкции на арест у прокурора не брались, проводи- лось ускоренное следствие, после чего производилось соответствующее оформление [4, Оп.1, Д.16778.Л.26].

Характерным примером технологии фабрикации уголовных дел того периода является дело на арестованного Корниз Степана Степановича 1901 г.р., уроженца c. Парканы Тираспольского района Молдавской ССР, болгарина, гражданина 
СССР, трудпоселенца, лесоруба Ключанской тракторной базы Добрянского района Пермской области [4, Оп.1, Д.16778. Л.16].

Корниз С.С. был арестован 15 декабря 1937 г. Пермским ГО НУКВД по подозрению в шпионаже и обвинялся в участии в антисоветской диверсионной организации. Какими материалами располагали органы НКВД при аресте Корниза С.С., из дела не видно. 21.12.1937 г. от арестованного Корниза С.С. были получены показания, что он состоял в диверсионноповстанческой организации, куда его завербовал некий агент эстонской разведки Кох Оскар Янович, по заданию которого Корниз С.С. поджигал дровяные склады и лесные массивы, а также проводил антисоветскую агитацию и пропаганду. В протоколе указано, что «членами антисоветской организации являлись также Киров В.И., Раичев З.Ф., Пильтек И.Ф., Грудолов Ф.Г., Добров П.С. и Радулов П.И.» Откуда именно Корнизу С.С. стало известно об участии в организации этих лиц и какую антисоветскую деятельность они проводили, на следствии не выяснялось.

К уголовному делу в качестве доказательств были приобщены выписки протоколов допросов арестованных по делам Грудолова Ф.Г. и Радулова Г.И., где Корниз С.С. значится как член антисоветской подпольной организации. По показаниям Грудолова Ф.Г., Корниза С.С. в антисоветскую организацию завербовал лично он сам. Эти показания вступают в противоречия с данными в личном деле о вербовке Корниза С.С. агентом эстонской разведки Кохом О.Я. Конкретная деятельность Корниза С.С. в организации никак не освещается.

Эти и другие обстоятельства, противоречия в показаниях Корниза, Грудолова и Радулова следствием не устранялись, сами показания не проверялись. При этом Корниз, проходивший как член антисоветской организации, завербованный эстонским агентом, 14 января 1938 г. комиссией НКВД и прокуратурой СССР был осужден как «немецкий» шпион, приговорен к высшей мере наказания и расстрелян.
Исходя из материалов дел, другие соучастники этой же антисоветской организации вместе с Корнизом С.С. обвинялись в диверсионно-повстанческой деятельности в пользу Болгарии (Радулов П.И.) и Эстонии (Радулов Г.И. и многие другие) [4, Оп.1, Д.16778. Л.16]. По материалам дел, Радулов П.И. являлся участником Болгарской диверсионно-террористической организации, был вовлечен в диверсионно-повстанческую организацию, одним из руководителей организации Стояновым В.Н [4, Оп.1, Д.16777. Л.7]. Из дела Стоянова В.Н. произведенным расследованием установлено, что он в 1935 г. был завербован в эстонскую диверсионно-повстанческую организацию [4, Оп.1, Д.14469. Л.5]. В данном отношении было совершенно не важно, на какую иностранную разведку работал Корниз С.С., как и то, что в разных делах он значится как агент эстонской или болгарской разведок, наиболее важным являлась постановка факта шпионажа в пользу недружественного государства в обвинительном заключении.

Фабрикация многих дел, поставленная буквально на конвейер, приводила к их грубым несостыковкам. Однако эти обстоятельства никем не учитывались до вынесения обвинительного приговора.

Еще одним наглядным примером, характеризующим делопроизводство периода репрессий конца 1930-х среди болгар, служит дело Радулова Г.И., упомянутого ранее по делу Корниза С.С. Радулов Григорий Иванович был арестован 16 декабря 1937 г. Пермским горотделом. Он обвинялся в диверсионно-повстанческой деятельности в пользу Эстонии. Следствием по делу было установлено: Радулов Г.И. отбывал ссылку в Добрянском районе, в 1935 г., где был вовлечен в Эстонскую диверсионно-повстанческую организацию одним из ее участников - Корневским Иваном Викентьевичем. По заданию организации в 1935 г. принимал участие в поджоге деревянного склада Добрянского леспромхоза. В 1936 г. участвовал в массовом поджоге лесных массивов. Призы- 
вал лесорубов к вооруженной борьбе с Советской властью. Виновным себя признал [4, Оп.1, Д.16778. Л.8]. Согласно документам, по делу Радулова Г.И. проходил также Корневский Иосиф Викентьевич, латыш, арестованный 13.12.1937 г. по подозрению в шпионаже. В деле имеется единственный протокол допроса обвиняемого Корневского, в котором указано, что Корневский завербовал Радулова Г.И. в польскую шпионско-диверсионную группу.

По факту, Радулов Г.И.обвинялся в участии в эстонской диверсионно-повстанческой организации и в ведении диверсионно-повстанческой работы [4, Оп.1, Д.16778. Л.8]. Обвиняемый Радулов Григорий Иванович, по протоколу 17 - эстонский шпион, осужден 15.01 .1938 , приговор был приведен в исполнение 21.02.1938 в 24 часа [4, Оп.1, Д.16778. Л.9]. В 1989 г. дело было пересмотрено. При проверке КГБ при СМ СССР, МВД СССР, Особому архиву Главного архивного управления при СМ СССР установлено, что в этих органах сведений о принадлежности к разведывательным службам империалистических государств Радулова Григория Ивановича, 1911 г.p., уроженца с. Парканы Тираспольского района Молдавской СССР, не имеется [4, Оп.1, Д.16778. Л.12].

На момент ареста никаких компрометирующих материалов, кроме того, что задержанные - ссыльные кулаки, не было. В целях быстрейшего проведения следствия все арестованные были разбиты на группы. В каждой группе было «выбрано» по одному арестованному в качестве руководителя повстанческо-диверсионной группы, и ему в протоколе допроса были внесены остальные участники, как им лично завербованные или связанные с ним по контрреволюционной работе... [4, Оп.1, Д.16778.Л. 30].

Протоколы допроса составляли таким образом, что сперва заполняли анкетную часть, а дальше, пользуясь собственной фантазией, указывали, что арестованный являлся участником повстанческо-диверсионной шпионской организации и про- водил диверсионную работу: «Первое время я не знал, что делать, так как арестованные или совсем не сознаются, или сознаются только в антисоветской агитации, а этого было недостаточно, но потом при помощи... я научился писать протокол так же, как писали и другие следователи бригады, т.е. называю арестованного, заполняю анкетную часть протокола допроса, а дальше сам составляю протокол допроса о том, что арестованный являлся участником повстанческо-диверсионной шпионской организации и проводил диверсионную работу. И подавал подписывать арестованному. Малограмотные, а таких было большинство, подписывали, не читая, а грамотных уговаривал подписать, что это нужно, что их просто переведут в другое место и т.Д., и в конце концов добивался подписи...» [4, Оп.1 Д.16778. Л.31]. Из показаний бывшего оперуполномоченного Пермского ГО НКВД Радыгина: «Таким образом, я, как и другие члены бригады..., составляли фиктивные протоколы допроса арестованных, вписывали им диверсии и шпионаж, хотя материалов, изобличающих их деятельность не было... Подписывались эти протоколы обманным путем, т.е. я им зачитывал автобиографические данные и совершенно не читал арестованным часть протокола о шпионаже и диверсии и они подписывали эти протоколы» [4, Оп.1, Д.11293. Т.2. Л.73].

Факты подбирались исходя из той сферы деятельности, к которой обвиняемый был непосредственно причастен. В Добрянском районе арестованные болгары трудились на лесозаготовках и на тракторной базе. В качестве состава преступления фигурируют вывод из строя тракторов, механизмов лесозаготовки, разбор железных дорог и прочее [4, Оп.1, Д.16778. Л.28]. Приведем некоторые фиктивные акты диверсий из обвинительных заключений материалов дел: «Радулов П.И., работая на тракторной базе слесарем умышленно недоброкачественно ремонтировал трактора, чем вызывал их быстрый износ и поломки. 
В 1937 г. на период уборочной кампании подверг порче большое количество хлеба» [4, Оп.1, Д.16777. Л.7]; «Раичев 3.Ф... в 1935 г. совместно с соучастниками... организовал и осуществил поджог колхозного склада с зерном в деревне Конино, погубив пожаром 20 тонн хлеба. В 1936 г. поджог два стога колхозного сена» и т.д. [5, Оп.1, Д.30460.Л.8].

Приведенные примеры оформления обвинительного заключения на Раичева 3.Ф., позволяют представить, в каком ускоренном режиме работал репрессивный «конвейер».

Ускоренные методы ведения следствия и последующего оформления приводили не только к грубым несостыковкам, но и к небрежному подбору фактов вымышленных преступлений; например, вышеупомянутый вымышленный инцидент с поджогом в д. Конино. Эта деревня находится на территории Нывенского района, на расстоянии более 150 км от места проживания Раичева З.Ф. в Добрянском районе в 1935 г. Чем обусловлен выбор этой деревни, достаточно удаленной от места проживания Раичева 3.Ф., в деле не приводится, как и не раскрываются обстоятельства преступления. Следующий инцидент с поджогом, якобы совершенным Раичевым 3.Ф., был произведен в 1936 г. Но в деле опять нет обстоятельств преступления - ни даты, ни времени, ни места. Погибших или получивших ранения в результате преступлений, приписываемых Раичеву 3.Ф., в деле не значится. Несмотря на это, в деле имеется информация о нанесённом ущербе, что само по себе, безусловно, является отягчающим обстоятельством и важным аспектом для построения обвинительного заключения.

После проведения арестов и соответствующего оформления - в обвинении значатся такие формулировки, как «участие в повстанческой группе», «шпионаж в пользу иностранных разведок», «подготовка к вооруженному восстанию болгартрудпоселенцев», а также перечисляются конкретные факты диверсий. Контрреволюционная деятельность, борьба с Совет- ской властью, выраженная в материальном «вредительстве», как правило, были дополнены антисоветскими выступлениями и прочими действиями, направленными против местной советской номенклатуры: Радулов Г.И. ...призывал лесорубов к вооруженной борьбе с Советской властью» [4, Оп.1 Д.16778. Л.8]; «Раичев 3.Ф. покушался на убийство парторга - председателя Избирательной комиссии Валдина, произведя в него выстрел в лесу» [5, Оп.1 Д.30460. Л.8]; «Пильтек Г.Ф. вел контрреволюционную пропаганду против социалистических методов труда» [4, Оп.1 Д.11992. Л.8]; «Стоянов В.Н ...призывал кулаков к вооруженной борьбе против Советской власти» [4, Оп.1 Д.14469. Л.5].

Таким образом, вымышленная деятельность обвиняемых была связана с порчей колхозного имущества, подготовкой к капиталистической войне, подрывом социалистического духа, антисоветской агитацией, покушением на жизнь чиновников местной администрации и т.п.

По завершении операции и приведении к исполнению приговоров сотрудники Пермского НКВД выезжали в п. Добрянку для получения фиктивных справок о вымышленных диверсиях и лесных пожарах. В дальнейшем эти справки были вложены в следственные дела арестованных [4, Оп.1 Д.16778. Л. 29].

\section{Внутренняя проверка и уголовные дела против сотрудников НКВД}

Весной 1938 г. количество арестов сотрудниками НКВД снижается. За смещением с должности организатора массовых репрессий в Свердловской области Дмитриева Д.М. последовала череда арестов уже сотрудников НКВД, проводивших массовые репрессии. Арестованным предъявили стандартное обвинение «участие в антисоветской заговорщицкой террористической организации, существовавшей в органах НКВД» [15, с. 102]. Таким образом, в 1938-1939 гг. Управлением НКВД Свердловской области в результате внутренних проверок было аре- 
стовано16 сотрудников Пермского ГО НКВД. «Материалами следствия было установлено, что сотрудниками Пермского горотдела НКВД Былкиным, Королевым и др. в 1937-1938 годах производились массовые аресты граждан по принципу национальной принадлежности, социального прошлого без наличия на них компрометирующих материалов... В целях создания шпионско-диверсионных и других повстанческих организаций указанными выше сотрудниками Пермского ГО НКВД применялись всевозможные противозаконные методы к арестованным. «Например, допрошенный в качестве обвиняемого бывший начальник отделения Пермского ГО НКВД Королев, признавая себя виновным в создании вымышленных контрреволюционных организаций, на допросе 22 мая 1939 года показал: «... Моя преступная деятельность началась с октября 1937 года, когда ко мне, как начальнику отделения, приходили ряд следователей для корректировки протоколов. Корректируя явно вымышленные протоколы и поправляя их, я вписал дополнения по шпионско-диверсионной деятельности этих арестованных (фамилии не помню), давал следователям предположительные вопросы и ответы для дополнения протокола и, таким образом, как начальник отделения, создавал вымышленные шпионско-диверсионные организации без наличия соответствующих материалов»... [4, Оп.1. Д.11293. Т.2. Л.72-73].

Обвинялись сотрудники Пермского ГО НКВД в том, что, будучи на оперативной работе в Пермском ГО НКВД, в период 1937-1938 гг. проводили массовые необоснованные аресты советских граждан и путем применения к ним преступных провокационных методов ведения следствия, подлогов и фальсификаций следственных документов искусственно создавали следственные дела о несуществующих контрреволюционных формированиях, т.е. в преступлениях, предусмотренных ст. 198 п. 17. УК РСФСР. Bсе обвиняемые, проходящие по данному делу, за исключением одного, в предъяв- ленном им обвинении, как на предварительном следствии, так и в судебном заседании виновными себя признали полностью и были 21-23 августа 1939 г. Военным Трибуналом войск НКВД Московского военного округа осуждены на различные сроки лишения свободы и ИТЛ.

\section{Пересмотр дел и период реабилитации}

Несмотря на то что внутренняя проверка выявила фальсификации по делам, пересмотр большинства из них начался лишь спустя почти 20 лет после вынесения приговоров.

Пересмотр дел был связан с целым комплексом причин. После смерти Сталина И.В. в 1953 г. в партийной жизни произошли существенные изменения. После ХХ съезда КПСС в 1956 г. был взят курс на «десталинизацию» и либерализацию общественной жизни. С этого времени начинается пересмотр массовых репрессий, итогом которых становится первая волна реабилитаций. С началом 1960-х гг. работа по пересмотру архивно-следственных дел пошла на убыль. [6, С. 38-41]. В 1960 г. с некоторых дел снимается гриф секретно. По многих болгарам фигурируют обзорные справки, по которым видно, что уголовные дела прекращены, однако их реабилитация происходит позже. Например, дело Радулова Петра Ивановича было прекращено в 1960 г., однако реабилитация произведена в 1975 г. [4, Оп.1 Д.16777. Л.9-10, 24]. Пересмотр большой части дел приходится на 1970-е - конец 1980-х гг. Именно с периодом «перестройки» связана вторая волна реабилитации. Таким образом, пересмотр дел растянулся на долгие десятилетия и завершился для болгар Добрянского района лишь в 1989 г. (см. табл. 2).

Некоторые обстоятельства периода реабилитации раскрываются из знакомства с письменными обращениями родственников, содержащими просьбы предоставить информацию о судьбах репрессированных. Так, например, в деле Стоянова В.Н. имеется письмо от его жены Стояновой Анны Сергеевны в адрес Во- 
енного трибунала УРВО от 7 декабря 1959 г.: «Прошу сообщить о судьбе моего мужа Стоянова В.Н., 1894 г.р., репрессированного 15 декабря 1937 г. Работал он в сельхоз артели поселка Верх-Исток Добрянского р-на Пермской области. Работал он десятником на лесозаготовках, бригадиром в артели, а в последнее время продавцом в магазине п. Верхний Исток. До сих пор о нем никаких известий не было. Прошу сообщить о его судьбе, т.к. сейчас многие получают известия в связи с пересмотром дел. Еще раз убедительно прошу не отказать в моей просьбе и сообщить мне по адресу... Для Стояновой Елены Алексеевны» [4, Оп.1 Д.14469. Л.13].

Следующее письмо было отправлено в адрес Прокурора Пермской области от 18 марта 1960 г. с просьбой рассмотреть заявление, отправленное ранее в адрес военного трибунала УРВО ранее: «Прошу прокурора Пермской области разобрать мое заявление в следующем: я писала заявление в Военный трибунал Уральского военного округа и просила, чтобы мне сообщили о судьбе моего мужа Стоянова Василия Никифоровича, репрессированного 15 декабря 1937 г. в пос. Верхний Исток Таборского с-совета Добрянсого р-на Молотовской обл. На моё заявление ответили, что дело Стоянова В.Н. в Военный трибунал УРВО для пересмотрения не поступало. Я убедительно прошу помочь о судьбе моего мужа, т.к. о других, которые были вместе с ним репрессированы (например, Киров Василий Иванович) есть известия. Ещё раз убедительно прошу сообщить мне о судьбе мужа по адресу... для Стояновой Анны Сергеевны» [4, Оп.1 Д.14469. Л.13].

Стоянова А.С. продолжает отправлять запросы направленные на выяснение судьбы мужа и обстоятельств смерти. В результате - помощник Военного прокурора Уральского военного округа направляет запрос на имя начальника Центрального государственного особого архива МВД СССР: «В связи с проверкой архивно-следственного дела прошу сообщить в Военную Прокуратуру Пермского гарни- зона, располагаете ли Вы сведениями о принадлежности к развед. органам быв. Буржуазной Эстонии: Стоянова В.Н., 1896 г.р.» [4, Оп.1 Д.14469.Л.22]. Далее поступают запросы на имя начальника учетно-архивного отделения УКГБ при СМ СССР по Пермской области, после для дополнительной проверки запрос отправляется на имя начальника следственного отдела комитета госбезопасности при СМ Молдавской ССР [4, Оп. 1 Д.14469.Л.23-25].

В итоге, в ответ на запрос Стояновой А.С. 18.03.1960 г. была составлена справка, что «в архивно-уголовном деле №759-Р на Стоянова Василия Никифоровича, 1896 года рождения, уроженца села Парканы, Тираспольского района имеется единственная учебная карточка по выселению кулачества, составленная НКВД Молдавской АССР в 1931 году. В данной учетной карточке говорится, что Стоянов имел 3,5 га пахотной земли, $2^{25}$ га виноградного сада, 2 лошади, одну корову и 10 овец. Хозяйство Стоянова является чисто кулацким, держал насильную рабочую силу, всегда старался скрыть объекта обложения, злостно уклонялся от уплаты налогов, являлся активным членом подпольного избиркома, ставил своей целью пропустить в сельсовет кулачество. К советской власти относился враждебно... Других материалов в деле не имеется. Сотрудник следотделения...» [4, Оп.1 Д.14469. Л.27].

В конце мая 1960 г. дело в отношении Стоянова В.Н. за отсутствием события преступления производством было прекращено, постановление Комиссии НКВД СССР и Прокурора СССР от 15 января 1938 г. отменено [4, Оп.1 Д.14469. Л.34]. После получения справки о реабилитации Стоянова В. Н. делает еще несколько запросов, направленных на выяснение всех обстоятельств смерти с целью оформления пенсии и подтверждения потери кормильца. В ответ на ее обращение оформляется запрос о регистрации смерти в исполнительный комитет Совета депутатов трудящихся с. Добрянки, куда поступает 
рекомендация выдать свидетельство, что Стоянов В.Н. умер в местах заключения 7 мая 1945 г. от острого воспаления тонких и толстых кишок дизентерийного характера. Ранее смерть Стоянова В.Н. зарегистрирована не была. Смерть Стоянова В.Н. зарегистрирована 27 февраля 1962 г., свидетельство о смерти Стояновой А.Н. выдано от 8 марта 1962 г. [4, Оп. 1 Д. 14469.Л.2-5].

Приведем еще один пример периода реабилитации - дело Кирова В.И., которое было пересмотрено в результате заявления о розыске со стороны его матери Кировой Екатерины Яковлевны в 1959 г. По факту проведения дополнительной проверки 26 мая 1959 г. определением № 678 Военного трибунала Уральского Военного округа решение прокурора и решение НКВД от 15 января 1938 г. в отношении Кирова Василия Ивановича отменено и дело прекращено за отсутствием состава преступления. Руководствуясь директивой КГБ при CM CCCP № 108 сс от 24. VIII/ 1955 г. Кировой Екатерине Яковлевне было рекомендовано объявить устно, что ее сын Киров Василий Иванович 15 января 1938 года был осужден на 10 лет ИТЛ, находясь в местах заключения умер, 22 октября 1945 г. от эмфиземы легких. В качестве рекомендации в деле значится оформление акта регистрации смерти Кирова Василия Ивановича через Управление милиции УМВД Пермской области в Добрянском гор (рай) бюро ЗАГС Пермской области, с указанием, что он умер 22 октября 1945 года от эмфиземы легких.

Фальсификация причины и места смерти Кирова В.И. - не единичный случай. Так, например, по делу Кирова Ивана Филипповича в ответ на запрос жены о судьбе мужа было принято решение дело прекратить за отсутствием состава преступления, жене сообщить что Киров И.Ф. умер 27 июля 1939 г. от упадка сердечной деятельности [4, Оп.1, Д.13828. Л.4]. Такой подход к пересмотру репрессивных дел периода «Большого террора» имел системный характер, особенно в самом начале - во второй половине 1950-х гг.
В результате репрессивной политики в отношении болгар в Добрянском районе Пермской области, из 14 болгар, репрессированных в период «Большого террора», высшую меру наказания получили 13 чел. Среди арестованных болгар Добрянского района, лишь одному удалось избежать высшей меры наказания. Им оказался Пильтек Г.Ф., 1917 г.р., уроженец дер. Парканы Тираспольского района МАССР, административно высланный в 1931 г. в пос. Кубовское Добрянского района. В 1934 г. Пильтек Г.Ф. со своей семьей был переведен в трудпоселок Верхний Исток, где работал, как подросток, в сельскохозяйственной артели и пас скот. С 1936 г. работал на лесозаготовках в Ключанском межлесопункте [4, Оп.1, Д.11992. Л.4]. После ареста 15 декабря 1937 г. ему, как и другим болгарам в этот период, было предъявлено обвинение в том, что он, «являясь участником Эстонской организации, проводил в Добрянском леспромхозе повстанческую работу, т.е. в преступлении, предусмотренном ст. 58-8-10 УК РСФСР [4, Оп.1, Д.11992. Л.8]. Следствие продолжалось в течение 3 месяцев, после чего Пильтек Г.Ф. был приговорен к 10 годам лишения свободы [4, Оп.1, Д.11992. Л.11]. В декабре 1939 г. Пильтеком было составлено заявление жалоба на имя прокурора СССР, в целью пересмотра дела: «...с начало до конца следствия шло односторонне. Следователь старался исключительно обвинять, а не выставлять действительность предъявленной обвинений... 10 летние наказание в 19-летнем возрасте я получил неповинно, все же не было факта о моей связи с к-р группы, если следователь полагает что я связан с к-р группы, то нужно было доказать потому что я не связан. ... Гражданин Прокурор прошу в последствии учесть, что я как молодой советский воспитанник не опустил руку, не бросил в панику, а наоборот добываю свою правду, находясь в трудовом лагере ежедневно в течении 370 дней беспрестанно, что высокие рекордные показатели производства в дело лесозаготовки и возке, и на 
сплаве, также свой опыт передаю десяткам другим даже... бригадирам сейчас мой бригадир выполняет производственной программы и ежедневно от 100-до 200... Гражданин Прокурор заканчивая свою жалобу остаюсь в ожидании от вас справедливый отклик в сторону защиты мне от не правильных наказаний» [1, Оп.1, Д.11992. Л.11-13]. 7 июня 1941 г. архивно-следственное дело вместе с жалобой Пильтека было направленно на дознание. В августе 1941 г. основное дознание произошло, ст. оперуполномоченный Добрянского РО НКВД... В заключении написано: «Следственное дело 8966 по обвинению Пильтека Г.Ф. в порядке приказов НКВД СССР 00762 и 00116 считать пересмотренным и дальнейшим следствием прекратить, приговор тройки УНКВД по Свердловской области на основании произведенного дополнительного следствия отменить и Пильтек Г.Ф. из трудлагеря освободить и дело сдать в 1 спецотдел УНКВД по МО для хранения» [6, Оп.1, Д.11992 Л. 14].

В начале 1957 г. Пильтек Г.Ф. продолжил борьбу за собственную реабилитацию обращением на имя начальника управления МВД Молотовской области: «В декабре 1937 г. я был арестован и посажен в тюрьму № 1 г. Молотова, в марте 1938 г. был отправлен в лагеря в Свердловскую область, сначала в Таборинский, а затем на ст. Азанка. Отбывал срок 10 лет по ст. 58. На суде я не присутствовал. За что был осужден - не знал. Прошу снять с меня пятно судимости или ответить мне, куда я должен обратиться с этой просьбой. Убедительно прошу дать мне ответ: 20 лет был неравноправным человеком не зная за что..» [6, Оп.1, Д.11992, Л.26-33]. В ответ на обращение Пильтека дело было прекращено в 1957 г.
Подводя итоги, следует заключить, что архивно-следственные дела «Большого террора» 1937-1938 гг. позволяют проанализировать как особенности репрессивной политики в отношении болгарского сообщества, так и особенности этнической истории болгар в регионе в этот период. Необходимо отметить национальный акцент репрессивной политики и связь репрессивной политики в отношении болгар Добрянского района Пермской области периода «Большого террора» с целым рядом «национальных» операций НКВД. [2, с. 185-195; 6]. За основу состава преступления брали национальную принадлежность арестованных, подданство, бытовое знакомство, родственные отношения арестованных. При этом уголовные дела выстраивались по шаблонному принципу наиболее грамотные среди арестованных назначались руководителями организаций, а остальные - рядовыми ее членами.

Большая часть задержанных болгар обвинялась в связях с разведкой иностранных государств, шпионской деятельностью в пользу иностранных разведок, не только болгарской, но и японской, эстонской, польской, германской и др. Проверка уголовных дел в 1938 г. показала их сфабрикованный характер. С 1956 г. начинается процесс пересмотра судебных дел по отношению к болгарам Добрянского района Пермской области. Процесс реабилитации болгар растянулся на долгие десятилетия и формально завершился в конце 1980-х гг. Безусловно, репрессивная политика периода 1937-1938 гг. в значительной степени повлияла на потомков болгар в регионе и на развитие болгарского сообщества в Добрянском районе в последующие годы.

\section{Библиографический список}

1. Вайман Д.И., Черных А.В. Немецкие хутора Прикамья: история и традиционная культура в XX - начале XXI в. - СПб.: Изд-во «Маматов», 2008. - 224 с.

2. Каменских М.С. Национальная политика в Прикамье в 1918-1939 гг.: региональный аспект. СПб.: Маматов, 2019. - 224 с.

3. Обухов Л.А. Будриса объявили главарем. Большой террор: польская «операция» (1930-1940 гг.). Пермские поляки. - Пермь: ОО «Раритет», 2001. - С. 66-73.

4. Пермский государственный архив социально-политической истории (ПермГАСПИ). Ф. 641/1 Архивные уголовные дела на лиц, снятых с оперативного учета в ИЦ УВД Пермского облисполкома, 1918-1991 гг. 
5. Пермский государственный архив социально-политической истории (ПермГАСПИ). Ф. 643/2 Архивные уголовные дела на лиц, реабилитированных по Указу Президиума Верховного Совета СССР от 16.01.1989. и Закону РСФСР от 18.10.1991.

6. Петров Н.В., Рогинский А.Б. Польская операция» НКВД 1937-1938 гг. [Электронный ресурс] Международное историко-просветительское, благотворительное и правозащитное общество «Мемориал». URL:// http://pmem.ru/index.php?id=115 (дата обращения 30.04.2021).

7. Станковская Г.Ф. Годы террора. Как делали «врагов народа»/ Электронная книга памяти жертв политических репрессий // Международное историко-просветительское, благотворительное и правозащитное общество «Мемориал». [Электронный ресурс] URL: http://kniga.pmem.ru/13-5-kak-delali-vragov-naroda.htm (дата обращения 28.04.2021).

8. Такала И.А. Большой террор в Карелии // Альманах североевропейских и балтийских исследований. - Вып. 3. - 2018. - С. 143-207. [Электронный ресурс] URL:// https://nbsr.petrsu.ru/journal/article.php?id=1066 (дата обращения 02.05.2021).

9. Черных А.В., Голева Т.Г., Каменских М.С., Шевырин С.А. Белорусы в Пермском крае: очерки истории и этнографии. - СПб.: Маматов, 2013. -240 с.

10. Черных А.В., Каменских М.С. Белорусы Перми: история и культура. - СПб.: Изд-во «Маматов», 2017. - 64 с.

11. Черных А.В. История болгар Прикамья 1920-1930-х гг. по материалам архивно-следственных дел // Вестник ПФИЦ. - Пермь. - 2020. - № 2. - С. 89-96.

12. Черных А.В., Филипова М.П., Каменских М.С. Болгары Перми: история и культура. - СПб: Изд-во «Маматов», 2018. - 64 с.

13. Черных А.В., Каменских М.С., Христов П.П. Болгары в регионах Урала в 1920-1930-е гг.: формирование и развитие этнодисперсной группы // Вопросы истории. - М. - 2020. № 10 (1). - С. 187-198.

14. Черных А.В, Кляус В.Л., Кляус М.П., Каменских М.С. Болгарское сообщество Пермского края: формирование, расселение, численность //. Вестник ПФИЦ. - Пермь, - 2020. - № 1. - С. 88-96.

15. Шевырин С.А. Топография террора: история политических репрессий. - СПб.: Изд-во «Маматов», 2012. - $240 \mathrm{c}$.

\title{
BULGARIANS OF THE PERM REGION DURING «THE GREAT TERROR»: «DOBRYNKAYA FOLDER»
}

\author{
D.I. Vaiman
}

Perm Federal Research Center UB RAS

\section{For citation:}

Vaiman D.I. Bulgarians of the Perm Region during «the Great Terror»: «Dobrynkaya folder» // Perm Federal Research Center Journal. - 2021. - № 4. - P. 82-95. https://doi.org/10.7242/2658-705X/2021.4.8

The article, based on archival materials, examines the history of repressions of Bulgarians in the Dobriansky region during the period of the «Great Terror». The so-called «Dobrianskaya folder» contains archival investigations in relation to Bulgarians who lived in the Dobriansky District of the Perm region at that time. It includes guilty verdicts, personal data, letters, autobiographies, interrogation records, references, answers to inquiries, and other documents. All these sources make it possible to define the sociocultural profile of Bulgarians in the Dobriansky region, as well as to present some circumstances of the repressive policy towards the Bulgarian community, which was carried out not only on social, but also on ethnic grounds during that period. It was in the Dobriansky District that the largest number of Bulgarians in the region suffered during «the Great Terror». Bulgarians subjected to repression were held in criminal cases under Art. 58-2-9-8-11 of the Criminal Code of the RSFSR as members of insurgent sabotage organizations.

Keywords: Bulgarians in Russian, history of Bulgarians in 1930s, archive cases, investigative cases, Bulgarians in the Perm Region.

\section{Сведения об авторе}

Вайман Дмитрий Игоревич, кандидат исторических наук, старший научный сотрудник отдела истории, археологии и этнографии, Пермский федеральный исследовательский центр УрО РАН (ПФИЦ УрО РАН), 614900, г. Пермь, ул. Ленина, 13А; e-mail: dmitrii-vaiman@yandex.ru 